\title{
Statyba
}

\section{PHENOMENON OF INERTIA IN CONSTRUCTION INDUSTRY}

\section{O. Kapliński}

To cite this article: O. Kapliński (2001) PHENOMENON OF INERTIA IN CONSTRUCTION INDUSTRY, Statyba, 7:4, 281-285, DOI: 10.1080/13921525.2001.10531737

To link to this article: https://doi.org/10.1080/13921525.2001.10531737

曲 Published online: 30 Jul 2012.

Submit your article to this journal $\widetilde{ }$

Џ Article views: 179

7 Citing articles: 1 View citing articles $\llbracket$ 


\section{PHENOMENON OF INERTIA IN CONSTRUCTION INDUSTRY}

\section{O. Kapliński}

Poznań University of Technology

\section{Introduction}

The paper deals with cases of risk in construction industry. We know, the realization of production processes, especially in the construction industry, very often occurs under random (stochastic) conditions, which considerably lowers their efficiency and introduces an element of risk in planning of their performance. Of course, the nature of risk has also many aspects, which are well described by Paslawski [1] and Kapliński [2]. This problem was also estimated by many authors, for example, by Zavadskas [3] and Bizon-Górecka [4] Aspects of the construction economics field are presented by Rutkauskas [5], Tamošiūnienè [6], Ye and Tiong [7]. New analytical approaches are described in [8], [9]. Miłosz designed an interesting method of digital simulation [10]. In order to analyze these aspects further, a system mapping is usually carried out. For this purpose, elements of the theory of reliability, among others, are employed. The application of so-called inertia is very interesting from the theoretical and practical point of view. The paper analyses the influence of the effect of inertia on the reliability of production systems.

\section{Problem position}

The traditional use of the probability

$$
\left[P(T>t)=e^{-\lambda t}\right] \text {. }
$$

of disruptions or the probability that the realization time $t$ will be kept is insufficient to the needs of engineering practice. Also, the investigation of a production system's efficiency by means of the queue theory (service systems) and simulation does not solve all the problems faced by a manager. Such notions as, eg, efficiency of action, costs, mechanization, technological processes are closely connected with the reliability of production. Increased demand in this respect, especially currently, implies the use of adequate methods for determining the reliability of processes which form the production process. An unsatisfactory level of applying reliability theory in the construction industry is due to several reasons:

Firstly, to the unique character of construction production, the complexity of these processes, various connections between them and the environment.

Secondly, to analytical difficulties and a small degree to which reliability and efficiency are connected.

The increase of production systems reliability may be obtained through two basic operations:

1. the application of adequate redundancy (ie, adding reserve elements to the system),

2. the application of the so-called inertia (series time-lag).

The paper analyses the influence of the effect of inertia on the reliability of production systems.

\section{The nature of inertia}

Systems inertia represents the phenomenon of continuing work for some time after the breakdown of one of the former phases. In our considerations, inertia is treated as the time elapsed from the onset of breakdown till the system's inability to work. Physical representations of inertia in production systems include storage yards, tank/containers, warehouses or even organizational solutions such as complex work crews which allow the system to continue work for some time; the latter is dependent on their size (defined in pieces, cubic meters, square meters, etc).

Results obtained during theoretical studies and observation of production processes in [11-21] permitted us to formulate the following thesis: the effect of inertia is an effective factor increasing the reliability of 
production systems. The phenomenon of inertia is intuitively identified by practitioners but has not been described and examined.

\section{Method of reliability analysis}

An analysis of these reasons helps to precisely define another approach to the evaluation of production system reliability. The prerequisites are considered in $[16,17,19,20]$.

Decomposition and synthesis of the system are very important elements of the method. The notion of systems reliability is expanded: apart from inefficiency resulting from the breakdown of machines and equipment, there is also inefficiency caused by improper functional structure, organizational factors, absenteeism, decreased workforce efficiency, shortages in material supplies etc.

Distribution of the ability time and distribution of the total work time of the system, determined on the basis of the distributions of ability and disability times of constituent elements of the system (or phases) determined during simulation are measures of reliability.

A programmed model of a production system (working as a simulator) is an investigation instrument. A model is a two-state one with a series structure. The structure of the programme is oriented to events of changes of both a phase state and a systems state. The actual version is programmed in GPSS language (cf, Miłosz in [10]). The simulator has been verified using three methods: statistical comparison of results with theoretical data, comparison with another simulation programme, and comparison of a simulator generated distribution with theoretical and empirical ones.

Investigations were carried out in numerous prefabrication plants and the following phenomena have been discovered:

- a variety of functional structures,

- the validity of the thesis about the series formulation of reliability structure with its variant solution of individual phases as subsystems,

- work time distributions and the non-functioning of mechanical devices near the exponential distribution,

- distributions of shortages of raw materials are symmetric (rectangular and normal).

Generally, a synthetic reliability model of a plant is fairly complex and individual analysis, due to a great number of elements (phases), is impossible.
The examples of simulation investigations of subsystems has been presented in $[11-13,14-17,21]$.

\section{Possibilities of increasing reliability of production systems}

The above-mentioned increase of production systems reliability may be obtained through two basic operations: adding reserve elements to the system (ie, adequate redundancy), the application of the so-called inertia.

The phenomenon of inertia often occurs in concrete prefabrication and rarely gets recognition as an excellent way of increasing reliability.

In order to compare both ways (redundancy and inertia) the work of a five-phase, series system, with different distribution of work and breakdowns but with identical mean values, eg, a work time of 150 time units, was analyzed. The results are presented in Fig 1.

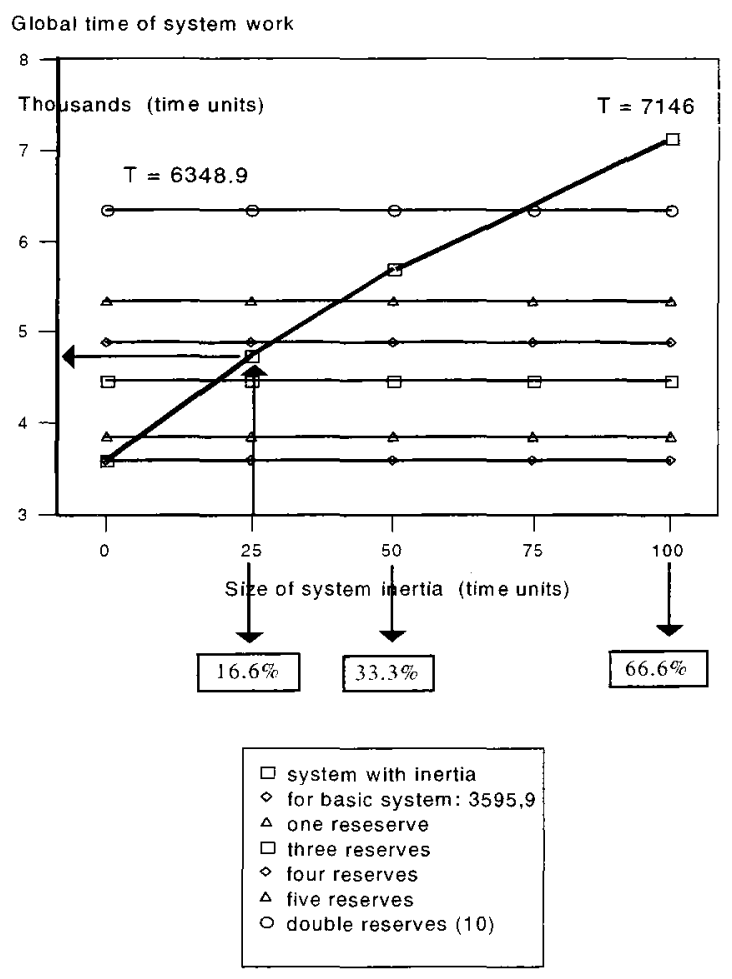

Fig 1. Comparison of the redundancy method and inertia method

The horizontal lines indicate the value of the system's global work time with a different number of redundancies (from 1 to 10 ). The oblique line indicates the system with inertia. Notice that only a $16 \%$ inertia (in relation to the mean work time of the phase) gives 
almost identical effects as the system with three redundancies.

\section{Simulated investigations of the inertia influence on the system reliability}

The results of this comparison encouraged further research. Simulated investigations of the influence of inertia on the reliability of a system were aimed at investigating the qualitative and quantitative influence of phase inertia on the system's reliable characteristics. The investigation results are as follows [21]:

Investigation 1: for a 4-phase system, ability of each phase $\mathrm{N}(5,1)$, disability of each phase $\mathrm{W}(1)$, inertia $(2$ time units) is placed (in succession) in phase 1,2 or 3 (where: N - normal distribution, $\mathrm{W}$ - exponential). Conclusion: when inertia approaches the last phase in the system, its influence on the shape of the distribution of the system's ability increases (the distribution changes from exponential - inertia equals zero - to nearly normal).

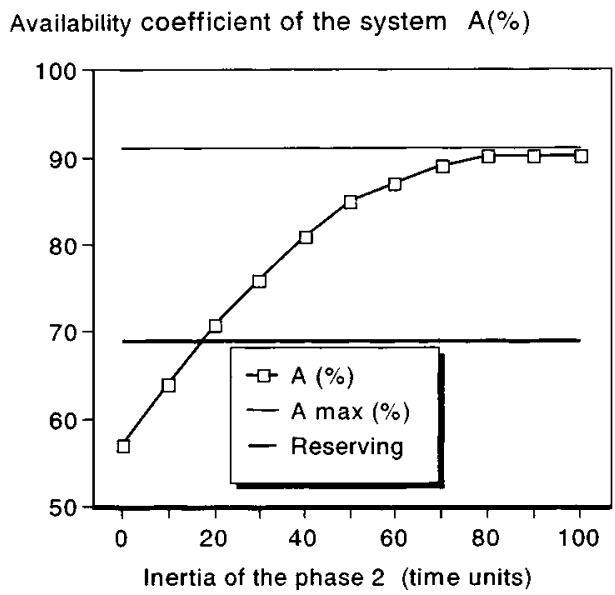

Fig 2. Dependence of the availability coefficient of the system on the inertia value in phase No 2

Investigation 2: for a 3-phase system, ability of each phase $\mathrm{N}(150,75)$, disability of phase $\mathrm{N}(50,25)$.

Conclusions ( $\mathrm{cf}_{2}$ Fig 2):

- an increase in inertia causes an increase in the availability of the system which approaches a certain border value,

- investigations with the use of reserve elements revealed ineffective use of more than one reserved element,

- limited possibility of increasing the availability coefficient when reserving is used,
- an increase in the system's availability is of an exponential character when inertia increases.

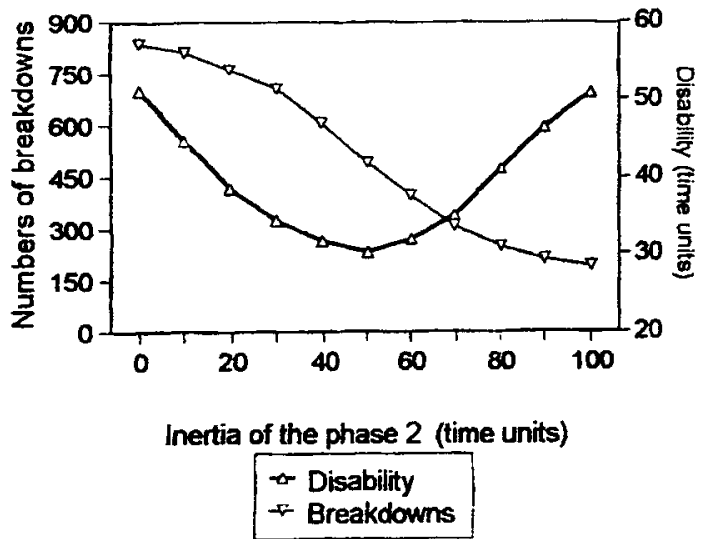

Fig 3. Dependence of the average time of a system's disability and the number of breakdowns on inertia in phase No 2

Investigation 3: system settings as in the investigation 2 .

Conclusion (cf, Fig 3): dependence of the average of a system's disability on inertia has a saddle-like character whereas dependence of the number of breakdowns (stoppages) in the system has the nature of an S-curve. Comment: inertia levels all disruptions which occurred at an earlier phase; later, there is saturation.

Investigation 4: for a 5-phase system, ability $\mathrm{N}(5,1)$, disability $W(1)$ with the same phases. Conclusions (cf, Fig 4):

- the effectiveness of using inertia to improve the availability (reliability) of a system depends on the place in the system's reliability structure in which it was taken into account. The closer the inertia to the end, the greater its influence on reliability. Possibly, in this way, one can explain the observed increased pace of work during the last stages of construction work. At that time, focus is put on the last contractor. This is a more or less analogous situation to investigation 4 , but is confirmed by the probability analysis of the finishing date of construction activities using the PERT method.

\section{Implementation}

The results (mentioned above) of theoretical findings with respect to the influence of inertia on the system's reliability were applied to a unique situation, in the "PREFABET" plant by Zakrat [21]. Production of small size cellular concrete elements was consid- 


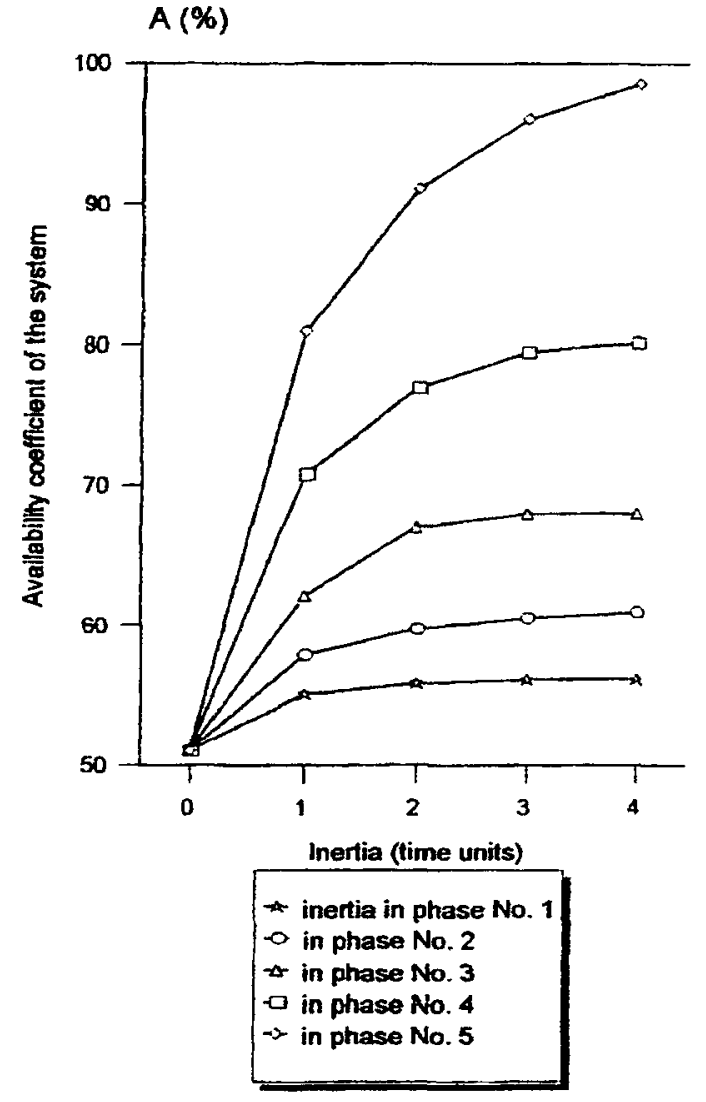

Fig 4. Dependence of the availability coefficient of a 5phase system on changes of inertia location in the system's structure

ered. The implementation of inertia proved very effective:

- instead of one reserve element, inertia in the order of $25 \%$ of the average time of an element's breakdown was sufficient;

- the use of inertia helped to obtain higher availability coefficients than the use of reserve elements.

Following an analysis of inertia in the plant's departments, it turned out that there was an opportunity for increasing inertia existing in production subsystems. For example:

- An inertia increase of the finished products storesite in subsystem PS- 5 by up to $180 \mathrm{~m} 2$ caused the reliability of the subsystem to approach one.

- Moreover, taking into account the increase in inertia in the transitory cement tank, when simulating a production system, an availability coefficient of 0.999 was obtained, ie, following proposed modernization of the production system an increase in reliability by $17 \%$ was obtained.
New theoretical discussions in this field of knowledge are presented in [22]. It is apparent that the inertia phenomenon rarely gets recognition as an excellent way for increasing reliability. A manager may also take into account the economic aspect of maintaining reliability at a specific level. He has to take into account technological requirements (eg, the number of redundant elements, the quantity of the required inertia), and, simultaneously, the effect in the form of the system's global work time. Depending on the cost structure of technical solutions mentioned above, he may select the most rational action. However, information on the influence of these solutions on the reliability of systems can only be gained through implementation of the proposed method and use of the simulator.

The author's experience proves that, from the formal point of view, simulation-heuristic procedures are most useful in the optimization mentioned above (ie, control of reliability).

The problem of control is placed in determining number $X_{i}(i=1,2, \ldots, n)$ of reserve elements in the $i$-th phase or determining quantity $Y_{i}(i=1,2, \ldots, n)$ of inertia units in the $\mathrm{i}$-th phase which are to maintain the desired level of reliability at minimal costs of redundancy or inertia generation. The simulation-heuristic procedure is described in $[11,19,22]$.

\section{Remarks}

The presented method of investigating and evaluating reliability and the simulator may be used not only in the construction industry, but also for analysis of other systems with recuperation. Both methods explain the mechanism of formation and influence of disruptions during production. They may even be used to analyze bad organizational structures. They will point out, then, those places which hinder production.

These methods like queue theory and service systems are preferred in cases of analyzing uniform production means, whereas the method presented in this paper (reliability) pertains to cases when the production system is simultaneously affected by a number of various factors - such as, for example, an organizational structure varying efficiency, when various production means occur and also when there is a shortage of them at different periods, when breakdowns occur, and when there is a shortage of workforce, etc. 


\section{References}

1. J. Pasławski. Some aspects of risk management in construction industry // Proc. lers Ateliers de recherche sur le risque en marketing. Universite Paris 1, 2000, p. 30/ $251-42 / 251$.

2. O. Kapliński. Modelling of construction processes. A managerial approach. KILiW PAN, Warsaw, 1997, 175 p.

3. E. K. Zavadskas. Zusammenhang zwischen der Mehrzweckselektierung und der Zuverlässigkeit im Bauwesen // Statyba, 1996, Nr. 2(6), S. 23-26.

4. A. Bizon-Górecka. Metodyka zarzadzania ryzykiem w produkcji budowlanej. ATR Press, Bydgoszcz, 1998 (Serie 89).

5. A. V. Rutkauskas. Computerized imitative technologies for risk and return trade-off // Proc. Zarzadzanie ryzykiem w przedsiebiorstwie. Ciechocinek - Bydgoszcz, 1999 , p. $115-140$.

6. R. Tamošiūniené. Rizikos analizès reikšmè statybos investiciniams projektams // Statyba, Vol V, Nr. 1, 1999. p. $59-67$

7. S. Ye, R. Tiong. NPV-at-risk method in infrastructure project investment evaluation // $\mathrm{J}$. Constr. Engrg. and Mgmt. ASCE, No.2000, p. 227-233.

8. R. Thomas, V. Sanvido. Role of the fabricator in labor productivity // J. Constr. Engrg. and Mgmt. ASCE, No 5, 2000 , p. $358-365$

9. O. Faniran, P. Love, H. Li. Optimal allocation of construction planning resources // J. Constr. Engrg. and Mgmt. ASCE, No 5, 1999, p. 311-319.

10. M. Miłosz. Badanie i ocena niezawodności systemów produkcyjnych w budownictwie // O. Kapliński (Editor). Informatyka stosowana $w$ inżynierii produkcji budowlanej Poznań: Poznań Univ. of Technology Press, 1996, p. 145 165.

11. E. Borucka. Metodyka badania i oceny niezawodności systemu produkcyjnego na przykładzie prefabrykacji betonowej. Ph.D.-Thesis / Poznań Technical Univ., Poznań, 1982.

12. R. Gruszeczka. Badania niezawodności produkcji wełny mineralnej w zakładach IZOLACJA w Cigacicach. MScThesis / Poznan Univ. of Technology, IKB, Poznań, 1993.

13. M. Przystańska. Badania niezawodności produkcji w Poznańskim Kombinacie Budowlanym. MSc-Thesis / Poznań Univ. of Technology, IKB, Poznan. 1986.

14. R. Tarnicki. Badania niezawodności zmodernizowanej linii produkcyjnej welny mineralnej ROCKWOOL w Cigacicach. M.Sc.-Thesis / Poznań Univ. of Technology, IKB, Poznań, 1995.

15. T. Tylec. Analiza struktur niezawodnościowych ciagów produkcyjnych na przykładzie Zakładu Produkcji Prefabrykatów w Poznańskim Kombinacie Budowlanym. MScThesis / Poznań Univ. of Technology, IOZ, Poznań, 1981.

16. O. Kapliński. Efficiency and reliability of the systems in the stochastic conditions // Project Management INTERNET'85, Elsevier Science Publishers B.V. (NorthHolland), 1985, 2, p. 835-842.

17. O. Kapliński. Some methodological problems of estimation of reliability of building processes. // Managing Construction Worldwide, Vol 2, London, E.\&F.N.Spon, 1987, p. 767-777.

18. O. Kapliński. Die Ausnutzung der Simulationstechnik zur Untersuchung und die Steuerung der Zuverlässigkeit von
Produktionsprozessen im Bauwesen // InformatikFachberichte, Band 109: Simulatiostechnik. SpringerVerlag, 1985, S. 517-521.

19. Report (No. 64-061/81) of Poznań University of Technology: Projektowanie ciagów technologicznych w budownictwie $z$ uwzględnieniem badań niezawodności i analizy zjawisk równowagi. Stage I-III, Poznań, 1981-1983.

20. Report of Poznań Univ. of Technology, IOZ, Metody automatyzacji kierowania i sterowania procesami technologicznymi w budownictwie. Stage I-II, Problem Nr. 1.11.01.4 of PAN and MNSzWiT, Poznań, 1979-1980.

21. S Zakrat. Wpływ bezwładności na niezawodność systemów technicznych na przykładzie produkcji materiałów budowlanych. Ph.D.-Thesis / Poznań Univ. of Technology, Poznań, 1992.

22. O. Kapliński, M. Milosz. Reliability of complex production systems // Civil Engineering Systems, Vol 13, 1995 , p. $61-73$.

\section{Acknowledgments}

This research was partially sponsored by Poznań University of Technology Grant BW 11-042/2001 and DS. I1$022 / 2001$

Iteikta 20010425

\section{STATYBOS PRAMONĖS INERTIŠKUMO FENOMENAS}

\section{o. Kapliński}

\section{Santrauka}

Straipsnyje nagrinejjama inercijos itaka gamybos sistemu patikimumui. Sistemos inercija apibūdina darbu tęstinumo reiškini, kai ankstesniu etapu ivyko avarija. Autoriaus nuomone, inercija gali büti apibūdinama kaị laikotarpis nuo sistemos avarijos momento iki momento, kai sistema pradeda veikti.

Sukurtas inercijos efekto jivertinimo metodas ir sudarytas algoritmas tam, kad būtu galima kontroliuoti gamybos sistemos patikimumą. Patikimumo analizès metodas pateiktas tik pranešimı aspektu. Taip pat pateiktos gamybos patikimumo sistemų tobulinimo galimybès. Lyginami perteklinis ir inercijos metodai. Šio palyginimo rezultatai ir inertiškumo poveikis sistemos patikimumui ir sudaro šio straipsnio esmę. Pagrindinès išvados: kai inertiškumas artèja prie sistemos paskutinès fazès, jo poveikis sistemai didèja; inertiškumo didejjimas sukelia sistemos pokyčius, kurie artẻja prie tam tikros reikšmès; sistemos trukdžiu vidurkio ittaka inertiškumui apibrěžiama balno formos priklausomybe, tuo tarpu itaka nuo trukdžių kiekio inertiškumui apibrėžiama $\mathrm{S}$ formos priklausomybe.

Oleg KAPLIŃSKI. Professor. Head of the Chair of Construction Engineering and Management. Poznań University of Technology, Piotrovo 5, 60-965 Poznań, Poland. E-mail: Kapleg@sol.put.poznan.pl

Author and co-author of 140 papers, articles and books. Member of Ukrainian Building Academy. Doctor honoris causa of Vilnius Gediminas Technical University. Member of Civil Engineering Committee of Polish Academy of Sciences. Chairman of the Division of Construction Management in this Committee. Research interests: organization and modelling of construction processes. 